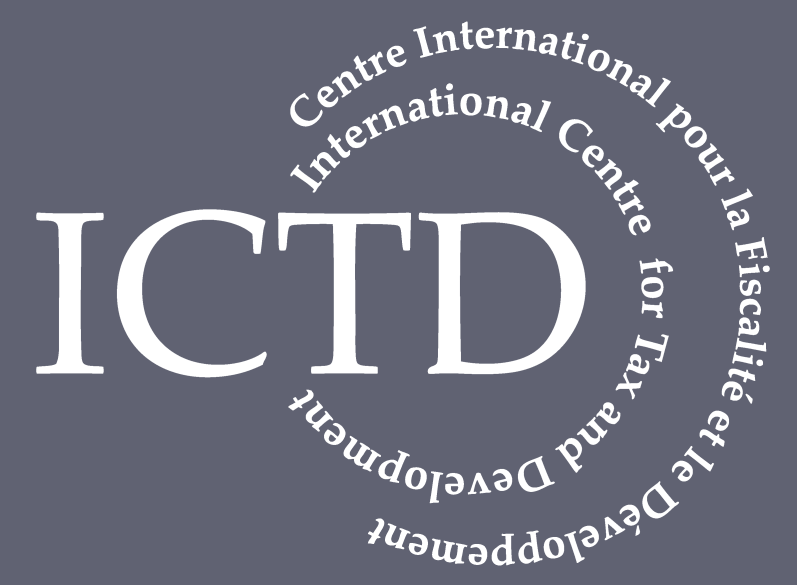

Working Paper 79

What Explains the Recent Calls for Reinstatement of a Tax Considered

Unpopular? An Analysis of Graduated Tax in Uganda

David Bakibinga, Jalia Kangave and Dan Ngabirano May 2018

BILL \& MELINDA

GATES foundation 
ICTD Working Paper 79

\section{What Explains the Recent Calls for Reinstatement of a Tax Considered Unpopular? An Analysis of Graduated Tax in Uganda}

David Bakibinga, Jalia Kangave and Dan Ngabirano

May 2018 
What Explains the Recent Calls for Reinstatement of a Tax Considered Unpopular? An Analysis of Graduated Tax in Uganda David Bakibinga, Jalia Kangave and Dan Ngabirano

ICTD Working Paper 79

First published by the Institute of Development Studies in May 2018

(c) Institute of Development Studies 2018

ISBN: 978-1-78118-446-2

\section{(c) (1) (8)}

This is an Open Access paper distributed under the terms of the Creative Commons Attribution Non Commercial 4.0

International licence, which permits downloading and sharing provided the original authors and source are credited - but the work is not used for commercial purposes. http://creativecommons.org/licenses/by-nc/4.0/legalcode

Available from:

The International Centre for Tax and Development at the Institute of Development Studies, Brighton BN1 9RE, UK

Tel: +44 (0) 1273606261

Email: info@ictd.ac.uk

Web: www.ictd/en/publications

IDS is a charitable company limited by guarantee and registered in England

Charity Registration Number 306371

Charitable Company Number 877338 


\title{
What Explains the Recent Calls for Reinstatement of a Tax Considered Unpopular? An Analysis of Graduated Tax in Uganda
}

\author{
David Bakibinga, Jalia Kangave and Dan Ngabirano
}

\begin{abstract}
Summary
Successful decentralisation relies heavily on the ability of subnational government to generate its own revenue. In many African countries, subnational government is authorised to collect a variety of taxes and user fees including trade licensing taxes, property taxes, market fees, garbage collection fees and road user fees. With the exception of property taxes, which have the potential to generate significant revenue, most other taxes collectively fund a very small proportion of subnational government budgets. Until recently, one of the main sources of own revenue for subnational government in Uganda was a poll tax known as graduated tax. Tanzania and Kenya had a similar tax, referred to respectively as the development levy and graduated personal tax. However, the tax was abolished in Kenya in 1974, in Tanzania in 2003 and in Uganda in 2005. The reasons for abolishing the tax in the three countries were similar, and included the fact that it relied on coercive enforcement, the costs of collection were quite high and it disproportionately affected the poor. In Uganda, however, there have recently been calls - within and outside government - for the reintroduction of the tax. Our research seeks to answer the question: what explains the calls for the introduction of a tax that was largely unpopular? We find two main explanations. First, graduated tax was the main source of revenue for local government in Uganda and there has been no adequate replacement for it. Second, the tax was a symbol of pride for some men, and encouraged productivity. Women - particularly in rural areas - feel that its abolition reduced the productivity of men.
\end{abstract}

Keywords: graduated tax; local government; nostalgia; politics.

David Bakibinga is Professor in the Department of Commercial Law, School of Law, Makerere University and author of Revenue Law in Uganda.

Jalia Kangave is a Research Fellow at the Institute of Development Studies, and Capacity Building Manager of the International Centre for Tax and Development (ICTD). She also leads the Gender and Tax programme at ICTD.

Dan Ngabirano teaches revenue law and taxation at the School of Law, Makerere University in Kampala, Uganda. He is also a Fulbright Scholar and SJD Candidate at the College of Law, University of lowa. 


\section{Contents}

Summary 3

Acknowledgements $\quad 5$

Acronyms

$\begin{array}{ll}\text { Introduction } & 6\end{array}$

$1 \quad$ Abolition of graduated tax in East Africa $\quad 7$

2 Why was the graduated tax suspended? 9

$3 \quad$ What explains calls for the reintroduction of graduated tax? 12

$\begin{array}{lll}3.1 & \text { Absence of a viable alternative to graduated tax } & 12\end{array}$

3.2 Graduated tax as a symbol of pride and productivity 16

4 Conclusion 19

$\begin{array}{ll}\text { References } & 21\end{array}$

Tables

Table 1

Table 2

Table 3

Sources of local government revenue 1997/98-2004/05

11

Analysis of total revenue from 17 urban councils 1996/97 and 1997/98

13

Local government revenue after abolition of graduated tax 14

Table 4

Rural urban revenue trends 


\section{Acknowledgements}

We are grateful to the International Centre for Tax and Development (ICTD) for providing the funding that made this research possible. We would also like to thank the School of Law at Makerere University for providing administrative support, including giving us feedback on the paper. We are indebted to Deus Mugabe and Hazel Birungi for their research assistance, and David Mutekanga and Patrick Lumala Zzimbe for their quantitative analysis. Lastly, we thank the anonymous referees for their comments on the earlier version of this paper. We take full responsibility for the contents of this paper.

\section{Acronyms}

ICTD

LHT

LGFC

LST

NRM

PAYE

SEATINI

TREP

URA

VAT
International Centre for Tax and Development

Local Hotel Tax

Local Government Finance Commission

Local Service Tax

National Resistance Movement

Pay As You Earn

Southern and Eastern Trade, Information and Negotiations Institute Taxpayer Registration Expansion Project

Uganda Revenue Authority

Value Added Tax 


\section{Introduction}

Three themes recur in the extensive literature on the financing of subnational government in anglophone sub-Saharan Africa. One is that subnational governments (with the exception of federal countries like Nigeria and Ethiopia) raise very little revenue themselves, and are therefore extremely dependent on whatever fiscal transfers they can obtain from higher levels of government, or, in earlier years, from aid donors (Fjeldstad 2016; IMF 2012; Jibao 2009). The second is that the process of revenue-raising at the local level in many, if not most, African countries is characterised by a high degree of informality and coercion, with the result that the actual burden of taxation is often very unfairly distributed, and can be quite high on some taxpayers (Jibao et al. 2017; Fjeldstad and Therkildsen 2008; Therkildsen 2006). The third is that where central government has managed to abolish these rather coercively collected and inequitable taxes - as is the case with graduated tax in Uganda, Kenya and Tanzania - the outcome has been almost universally positive and welcomed (Fjelstad 2016; Fjeldstad and Therkildsen 2008). We are not here challenging the first two elements of this standard narrative. Indeed, we broadly accept them. We are, however, challenging the third element: the notion that the abolition of graduated tax in East Africa was unambiguously a good thing.

Stimulated by reports that showed nostalgia for graduated tax among segments of Uganda's population, we conducted research to establish the arguments for and against reintroduction of the tax. Our research relied on two main methods. The first was a desk study of primary and secondary literature, including laws, government reports, newspaper articles, academic articles and other publications. The second was interviews with various stakeholders, including central government officials, local government officials, representatives from civil society organisations, chiefs and community members between late 2016 to mid-2017. Our fieldwork was conducted in eight districts, which we selected on the basis of their location and the yield from graduated tax before it was abolished. ${ }^{1}$ In each district we interviewed several local government officials and chiefs. We also held focus group discussions in three of the districts,. The interviews and focus group discussions were aimed at understanding the impact of the abolition of graduated tax on subnational government and citizens. In total, we interviewed forty local government officials - chief administrative officers, town clerks, treasurers, accountants, revenue officers, planners, finance officers and local council chairpersons. We also interviewed five chiefs and one prison officer. At the central government level, we spoke with officials from the Local Government Finance Commission (LGFC) and officers in the Tax Policy Department of the Ministry of Finance Planning and Economic Development. Similarly, we conducted four focus group discussions in three districts with a total of thirty-four participants. Lastly, we spoke with representatives from three civil society organisations: Civil Society Budget Advocacy Group, Uganda Debt Network, and Southern and Eastern African Trade, Information and Negotiations Institute (SEATINI).

We found that there was considerable support for the reintroduction of graduated tax in some quarters. We also discovered that, unlike Kenya and Tanzania, the original decision to abolish graduated tax in Uganda was politically quite contentious, with a significant amount of support for its retention in the Ugandan Parliament. More specifically, there seem to be three sources of support for reintroducing the tax after its abolition:

We visited Kampala, Mbarara, Kabale, Kisoro, Gulu, Moroto, Kapchorwa and Tororo. 
1. The majority of government officials at the subnational level would like the tax reintroduced. This is not surprising given the fact that they got a bad deal out of its abolition.

2. Some women are in favour of its reintroduction. The basic grounds for this seem to be that they perceive graduated tax as a way of obliging lazy husbands to go to work.

3. Perhaps more surprising, some men also retain nostalgia for the tax. On the face of it, this is difficult to explain on grounds of rational self-interest. However, it can be explained from the perspective of the social standing that was associated with having the financial resources to honour one's tax obligations.

We are conscious of the fact that our sample of interviewees is too small to be representative of the broader perceptions of Ugandans. There is a need for a much larger sample of participants to draw concrete policy conclusions. However, our research casts a spotlight on a narrative around the abolition of graduated tax that is largely ignored in existing literature: there are segments of the population who, for various reasons, are nostalgic for the tax.

Our discussion is divided into four sections. In Section 1, we discuss in some detail the circumstances under which graduated tax was abolished in Kenya, Tanzania and Uganda. This is followed in Section 2 by a discussion of the reasons behind the abolition of the tax. In Section 3, we examine why there are calls from certain segments in Uganda to have it reinstated. We conclude the discussion in Section 4.

\section{Abolition of graduated tax in East Africa}

Poll taxes (also known as head taxes) were introduced by colonialists in various parts of Africa, to supplement or replace colonial hut taxes (Gardner 2012). These taxes served two major purposes. On the one hand, they were a basic source of general government revenue used to sustain colonial administration and support war efforts (Waris 2007; Fjeldstad and Therkildsen 2008; Gardner 2012). On the other hand, taxation was used as an instrument to force Africans to work for wages for the colonial government and white settlers or to cultivate cash crops on their own land. Many African countries continued to levy these taxes even after independence. In many countries, however, poll taxes were handed over to subnational governments once central governments got other significant sources of revenue, such as income tax, value added tax, and excise and customs duties. Poll taxes constituted the main source of own revenue for many post-independent subnational governments. In Uganda, for example, until its abolition a poll tax known as graduated tax was the main source of own revenue for most subnational governments. Introduced by the British in 1954, graduated tax was intended to generate revenue for the day-to-day running and operations of the colonial administration (Vallibhoy 1965; Davey 1974). It was imposed on all able-bodied men over the age of eighteen (irrespective of whether or not they were engaged in gainful employment), and women in gainful employment.

A similar tax, known as the development levy, existed in Tanzania to facilitate local development projects, including the construction of roads, schools and dispensaries (Kjaer and Katera 2017). In Kenya, a mass tax known as graduated personal tax was introduced in the late colonial period to serve a similar purpose (Waris 2007). Kenya was the first of the three countries to completely abolish the tax. In 1973, the Minister of Finance proposed in parliament that graduated personal tax should be abolished on the grounds that there was a need to move away from direct taxation of poor members of society (Kenya National 
Assembly 1973). There was huge support for the minister's proposal because the tax was perceived as being regressive, its enforcement was coercive and it was sometimes used as an instrument of oppression by those in power (Kenya National Assembly 1973; Kwatemba 2017; Tarus and Njoroge 2015).

In Tanzania, the development levy (then simply known as the poll tax) was first abolished in 1969 , following mass public protests after thirteen people died in a prison that was overcrowded with tax defaulters (Fjeldstad and Therkildsen 2008). The tax was reintroduced in 1984, and was this time referred to as the development levy. It was finally abolished in 2003. The decision to abolish the development levy was not discussed in parliament (Kjaer and Therkildsen 2013; World Bank 2006). Instead, the Minister of Finance announced in his 2003 budget speech that the government was going to abolish the tax, because there had been complaints 'from ordinary people and business entities on the nuisance caused by revenue collection'. Among the reasons for its abolition was the harsh enforcement, its regressive nature and the fact that the revenue collected was used largely to finance operational costs of local government instead of financing development projects (Fjeldstad and Semboja 2000; Kjaer and Therkildsen 2013).

Unlike Kenya and Tanzania, in Uganda the government did not opt for an outright abolition of graduated tax. In April 2004, a member of parliament moved a motion to sponsor a private members' Bill proposing the abolition of graduated tax (Parliament of the Republic of Uganda 2004). He argued that the tax should be abolished because it:

(a) was a colonial legacy that continued to haunt the country

(b) resulted in double taxation since it was not much different from Pay As You Earn (PAYE)

(c) made poor people worse off

(d) was vulnerable to manipulation by politicians

(e) was regressive

(f) resulted in riots and even death in some cases

(g) was rarely used for the benefit of local communities

(h) was characterised with expensive and coercive enforcement

(i) made local government dependent on it instead of exploring other revenue sources.

Those supporting the abolition of the tax also noted that Uganda was the only country in East Africa that still levied that kind of poll tax. Kenya had long abolished the tax, and Tanzania had done so the previous year.

While parliamentarians in Kenya had shown overwhelming support for the abolition of graduated personal tax in 1973, the reaction in Uganda's parliament was mixed, and in fact quite split. Out of a total of ninety-three members of parliament, five members abstained from voting on the motion, thirty-nine voted against and forty-nine voted in favour of it. Later that month, at a caucus meeting of the ruling political party (National Resistance Movement (NRM)), the president announced that graduated tax would be suspended for a period of ten years starting in FY2005/2006 (Osike 2004). He argued that, given the low income levels of most households, it was better to raise revenue from indirect taxes on consumer goods instead of taxing the poor through direct taxes. The following month, the vice president of Uganda emphasised the fact that the government was suspending - not abolishing - the tax, stating that: 
It should be understood that the tax has not been abolished. It is only being suspended for a specific period. ... During the next ten years therefore, we need to mobilise our people to raise a minimum income of at least Sh10million in each household so that in future when the tax is reinstated they are equitably taxed. (Vision Reporter 2004)

This distinction between the initial stance taken by Uganda and that of the other two countries is important, because it explains in part why there were calls for the tax to be reintroduced ten years later. Before the ten-year period was over, however, in 2008 the government of Uganda announced that it was abolishing graduated tax and replacing it with two other taxes: the local service tax and local hotel tax (Local Government Finance Commission 2012). Since then, there have been calls from civil society organisations, ${ }^{2}$ sections of government ${ }^{3}$ and even the general public (particularly individuals in rural areas) ${ }^{4}$ for the tax to be reintroduced.

\section{Why was graduated tax suspended in Uganda?}

There is hardly any debate about the fact that government policy on graduated tax was often very political. On numerous occasion, politicians publicly criticised the tax, and sometimes even arbitrarily told people that they were exempted from paying it (Local Government Finance Commission 2012). Indeed, the debate on whether or not the tax should be scrapped was initiated in the context of the highly charged 2001 presidential election (Ndawula 2009; Kizza-Besigye 2001; Fjeldstad and Therkildsen 2008). In the course of the campaign the main opposition candidate, Kizza Besigye, decried the tax as being a colonial relic and oppressive to everyday citizens. He promised to scrap it once elected into office. This won him support of especially the rural poor, who viewed the tax as oppressive. Amidst the threat of losing support from the rural population, which had since 1986 formed the core support of President Museveni and the NRM, the latter announced that his government would look into a comprehensive reform of the tax once elected in 2001. At the time, he promised that the reform would be geared towards ensuring that the enforcement of graduated tax was more friendly, and that the tax itself was affordable to everyday citizens. Following the 2001 election, the minimum tax payable was reduced from UGX11,000 to UGX3,000 per year (Bahiigwa et. al. 2004). Later, in 2004, in the face of what would be another heated presidential election in 2006, the president announced that the tax would be suspended effective 2005 (Kjaer and Therkilsen 2013).

Graduated tax was defined as 'a crude form of income tax levied in Uganda upon the entire population of able bodied adult males and some women by the District Administration and

\footnotetext{
See, for example, Ismail Musa Ladu, 'Civil society organisations want graduated tax back', <http://www.monitor.co.ug/Business/Civil-society-organisations-wants-graduated-tax-back/688322-2692868oqqrii/index.html>; Ismail Musa Ladu (2016) 'Government quashes idea of restoring graduated tax', <http://www.monitor.co.ug/Business/Prosper/Government-quashes-idea-of-restoring-graduated-tax/688616-3154902pttfu2/index.html>; Bernard Busuulwa, 'Uganda: Proposal for return of graduated tax opposed', <http://www.theeastafrican.co.ke/business/Uganda-Proposal-for-return-of-graduated-tax-opposed--/2560-3172218II55cuz/index.html>.

Interviews with researchers in 2016 and 2017. Ismail Musa Ladu (2016) 'Government quashes idea of restoring graduated tax', $<$ http://www.monitor.co.ug/Business/Prosper/Government-quashes-idea-of-restoring-graduated-tax/688616-3154902pttfu2/index.html>.
} 
Urban Authorities where they reside' (Davey 1974: 31). It was levied on income, actual or presumed, from all sources, including land and other assets used for subsistence (Ghai 1966: 19). It was administered by local authorities under powers conferred by the local Government Act (Chap. 243 Laws of Uganda). Assessment of the tax was made by a tax assessment committee or assessment officer appointed by the District or Urban Local Council for that purpose (Bakibinga 2012: 16-17). Only adults of 18 years of age and above residing in the particular area were assessed. Certain persons, including visitors to the particular local council, students and diplomatic and consular personnel were exempt from payment of the tax (Local Government Act, Fifth Schedule). Allowances were paid to local and security officials involved in collection.

Graduated tax had become unpopular for various reasons, and was thus easy to use as political bait. First, the tax relied heavily on harsh enforcement. Frequently, particularly in rural areas, armed local defence units were used in tax collection; tax defaulters were beaten, arrested and sometimes taken to unknown destinations, and in extreme cases imprisoned (Fjeldstad and Therkildsen 2008; Livingstone and Charlton 1998; interviews with officials in Mbarara District Local Council; Parliament of the Government of Uganda 2004). Sometimes defaulters slept in bushes at night to hide from tax collectors (interview with local government officials in Gulu District). There was at least one report of a tax defaulter being beaten to death by tax collectors, and others sustaining injuries from gunshots that were fired in the process of collecting taxes (Livingstone and Charlton 1998). Frequently, if not always, it was poor people who bore the brunt of the harsh enforcement. ${ }^{5}$

Second, the tax was regressive (Republic of Uganda 1987). While various tax bands were provided for under the law, in practice these bands did not affect the actual tax incidence (Fjeldstad and Therkildsen 2008; Mugume 2004). A number of factors made the tax regressive. To begin with, it was difficult to assess the real income of peasants who relied primarily on rain for farming - meaning that they sometimes paid taxes even when their harvest had gone bad. Many times, poor people had to sell their land or livestock to fulfil their tax obligations (interviews with community members in Butunza and local government officials in Gulu District). Additionally, political pressure often obstructed collection, and determined who paid taxes. Often the poor paid, while the rich were let off the hook (Bahiigwa 2004). ${ }^{6}$ Lastly, because of inefficient tax administration, it was fairly accidental who ended up paying tax and how much they paid. Many assessments were made in a crude and presumptive manner (Therkildsen 2006). In a survey conducted in three districts in 2001, for example, it was found that households in the lowest quartile paid a share of their income that was about three times more than that paid by households in the highest income quartile (Bahiigwa 2004). Sometime, individuals earning income at similar levels were taxed differently as a result of being in different locations (Therkildsen 2006). ${ }^{7}$

5 In a survey conducted in 2000 of 56 central government prisons and 139 local government prisons, for example, it was found that in central government prisons 79 people were convicted and 304 people (around $5 \%$ of all those remanded) charged with failure to pay graduated tax (Therkildsen 2006). Most of the inmates were poor people, whose financial situation made them unable to pay their taxes to avoid imprisonment, or unable to pay bribes to prison officials for their release. The survey also found that 14 of the $74(19 \%)$ individuals convicted received longer sentences than the statutory sentence, while $57 \%$ received the legal maximum of one month. Only $25 \%$ got a shorter sentence than the legal maximum.

$6 \quad$ In Kapchorwa district, for example, there were a sizeable number of successful businessmen, opinion leaders and local political leaders and elders whose names were not on the graduated tax register in 1996 (Mukasa 2002). Some of these chronic defaulters were as highly placed as local council chairpersons, and members of the district councils and committees. Even some of those who appeared on the register stubbornly refused to pay.

Thus, for example, in an analysis of a selection of districts in 1992-1993, it was found that there were great variances in the taxes paid in the different districts, and that these variances did not reflect the income levels in those districts (Livingstone and Charlton 1998). For example, in Iganga (a comparatively well-off district) it was found that over $50 \%$ of taxpayers paid UGX4,000 or less in graduated tax, while in Lira (a much poorer district) $86 \%$ paid between UGX7,000 and UGX12,000. 
Third, there was a widespread sentiment among taxpayers that the taxes collected were not used to fund local services. Even though initially there was some evidence of the taxes being used to fund projects that benefited local communities, by the early 2000 s many felt that the revenue collected was mostly used to fund the administrative expenses of local government (Fjeldstad and Therkildsen 2008; Livingston and Charlton 1998). ${ }^{8}$

Fourth, and related to the above, there was a general perception among taxpayers that the whole process of assessment, collection and use of the tax was riddled with corruption. In some cases tax officials were accused of embezzling revenue for personal gain (Kjaer 2009). Similarly, local government officials were accused of conniving with taxpayers for the latter to pay the least amount of taxes (Mugume 2004). This had a negative impact on tax morale.

To make matters worse, the cost of collecting the tax was often quite high. In a study conducted in fifteen higher and twenty-five lower local government institutions, it was estimated that on average the collection costs incurred by lower local government institutions were 25 per cent of the taxes collected, while higher local government institutions spent 22 per cent on collection (Development Consultants International Limited 2005). In some districts the collection costs would exceed 30 per cent of the taxes collected (Livingstone and Charlton 1998).

Fifth, even though graduated tax constituted a significant percentage of the revenue collected by local government, its actual contribution to total local government financing was quite small. As Table 1 shows, in the late 1990s graduated tax contributed 8 per cent of total local government revenue; a figure that dropped significantly to under 2 per cent in $2004 / 2005$.

Table 1 Sources of local government revenue 1997/98- 2004/05 ${ }^{9}$ (UGX billion)

\begin{tabular}{|cccccc|cccc|}
\hline & \multicolumn{5}{c|}{ Local government Revenue } & \multicolumn{4}{c|}{ Revenue Share (\%) } \\
F/Y & GTax & Other Taxes & Grants & Other Rev & Total Rev & GTax & Other Taxes & Grants & Other Rev \\
\hline $1997 / 98$ & 21.8 & 19.9 & 218.5 & 14.4 & $\mathbf{2 7 4 . 6}$ & $7.9 \%$ & $7.3 \%$ & $79.6 \%$ & $5.2 \%$ \\
$1998 / 99$ & 19.8 & 20.6 & 319.3 & 16.0 & $\mathbf{3 7 5 . 7}$ & $5.3 \%$ & $5.5 \%$ & $85.0 \%$ & $4.3 \%$ \\
$1999 / 00$ & 17.1 & 22.7 & 392.8 & 17.5 & $\mathbf{4 5 0 . 1}$ & $3.8 \%$ & $5.0 \%$ & $87.3 \%$ & $3.9 \%$ \\
$2000 / 01$ & 15.5 & 20.2 & 513.2 & 23.4 & $\mathbf{5 7 2 . 3}$ & $2.7 \%$ & $3.5 \%$ & $89.7 \%$ & $4.1 \%$ \\
$2001 / 02$ & 25.5 & 13.7 & 624.8 & 24.5 & $\mathbf{6 8 8 . 5}$ & $3.7 \%$ & $2.0 \%$ & $90.7 \%$ & $3.6 \%$ \\
$2002 / 03$ & 29.8 & 13.7 & 705.6 & 27.2 & $\mathbf{7 7 6 . 3}$ & $3.8 \%$ & $1.8 \%$ & $90.9 \%$ & $3.5 \%$ \\
$2003 / 04$ & 29.5 & 12.1 & 728.1 & 29.5 & $\mathbf{7 9 9 . 2}$ & $3.7 \%$ & $1.5 \%$ & $91.1 \%$ & $3.7 \%$ \\
$2004 / 05$ & 16.1 & 31.8 & 848.9 & 31.6 & $\mathbf{9 2 8 . 4}$ & $1.7 \%$ & $3.4 \%$ & $91.4 \%$ & $3.4 \%$ \\
\hline
\end{tabular}

Source: Local Government Finance Commission. ${ }^{10}$

The combination of the above factors made graduated tax quite unpopular, and the target of a number of protests. In 1984, for example, citizens staged protests against the government because of a tenfold increase in the tax (Mamdani 2008). In 1994, residents of Iganga, a district in the eastern part of Uganda, protested against unfair assessments of graduated tax (Kjaer and Therkildsen 2013; Fjeldstad and Therkildsen 2008). Similarly, in 2002 a riot broke out at a factory in western Uganda where workers were striking because of over-assessment

\footnotetext{
8 In an interview with SEATINI officials the researchers were informed that in some cases council meetings alone exhausted the revenue that had been collected. In Gulu, expenses such as allowances and fuel for local government officials often consumed the taxes that had been collected (interview with local government official in Gulu district). These figures represent the contribution of graduated tax to total local government revenue including grants from central government.

2016 data from draft report on file with LGFC.
} 
of graduated tax (Parliament of Uganda 2002). One person was shot dead and two others were wounded.

Yet, despite all these factors, ten years after its suspension certain factions in the population were calling for reintroduction of the tax. One of the things we sought to understand was: what explained the apparent nostalgia for a tax that had been largely unpopular? Even more intriguing, why would a segment of the population that often bore the brunt of enforcement directly or indirectly - yearn for reintroduction of the same tax? We answer these questions in the next section.

\section{What explains calls for the reintroduction of graduated tax?}

There are various similarities in the events surrounding the abolition of graduated tax and development levy in Uganda, Kenya and Tanzania. In all three countries the taxes were abolished close to presidential elections (Kenya National Assembly 1973; Kjaer and Therkildsen 2013). In Tanzania and Uganda, we were able to trace opposition to abolition of the tax from some segments within government, particularly local government officials in both countries and some members of parliament in Uganda (World Bank 2006). In Kenya, however, the minister's proposal to abolish the tax was met with great enthusiasm in parliament, with members observing that the tax was unfair, regressive and that it was often used to oppress those that tax collectors had grudges against (Kenya National Assembly 1973). Despite these similarities, it is only in Uganda that there has been a public debate inside and outside government about whether graduated tax should be reintroduced. The immediate explanation for this could be the fact that originally the Government of Uganda announced that it was suspending, rather than abolishing, the tax. It is thus no wonder that ten years after the announcement the debate was revived. However, this explanation on its own is insufficient - particularly given the fact that the government later (in 2008) abolished the tax and replaced it with the local services tax and local hotel tax.

We find two explanations for the nostalgia for graduated tax. The first is not entirely surprising. Subnational government officials calling for reintroduction of the tax complain that graduated tax was the main source of locally generated revenue, and there has been no adequate replacement since its abolition. The second origin of the call to reintroduce the tax is somewhat surprising, because it comes from a segment of the population that often bore the brunt of the tax - directly and/or indirectly. It is the nostalgia of men and women in rural Uganda. For this group, graduated tax was a symbol of pride and encouraged productivity. We discuss these explanations in detail below.

\subsection{Absence of a viable alternative to graduated tax}

Graduated tax was the major source of locally generated revenue for many subnational governments. According to the LGFC, at the time it was scrapped revenue from graduated tax constituted 66 per cent of all subnational government own source revenue. The abolition of the tax is also reported to have created an immediate revenue shortfall of UGX60 billion (Local Government Finance Commission 2012). This was exacerbated by inadequate compensation for it from central government, and the poor performance of the local services 
and local hotel taxes that had been introduced to replace it and effectively provide alternative revenue, particularly in rural areas. This left many subnational governments with hardly any revenue; this situation has been exacerbated by the ever-insufficient fiscal transfers from the central government.

As Table 2 below shows, urban councils were even more affected by the abolition of graduated tax, since most of them depended highly on revenue collection from graduated tax. In 1996/97, for example, councils such as Bombo, Bushenyi and Mpigi collected between 44 per cent and 53 per cent of their revenue from graduated tax, and did not rely on any funding from the central government.

Table 2 Analysis of total revenue from 17 urban councils 1996/97 and 1997/98

\begin{tabular}{|c|c|c|c|c|c|c|c|c|c|c|}
\hline \multicolumn{11}{|c|}{ Analysis of Total Revenue from 17 Urban Councils for the years 1996/97_1997/98 } \\
\hline \multirow[t]{2}{*}{ Urban Council } & \multicolumn{5}{|c|}{$1996 / 97$} & \multicolumn{5}{|c|}{$1997 / 98$} \\
\hline & GRAD TAX & GOU FUNDS & DONOR FUNDS & OTHER & TOTAL & GRAD TAX & GOU FUNDS & DONOR FUNDS & OTHER & TOTAL \\
\hline Bombo TC & $44 \%$ & $0 \%$ & $0 \%$ & $56 \%$ & $100 \%$ & $23 \%$ & $35 \%$ & $0 \%$ & $43 \%$ & $100 \%$ \\
\hline Bushenyi TC & $53 \%$ & $0 \%$ & $0 \%$ & $47 \%$ & $100 \%$ & $32 \%$ & $19 \%$ & $0 \%$ & $50 \%$ & $100 \%$ \\
\hline Entebbe MC & $31 \%$ & $19 \%$ & $0 \%$ & $50 \%$ & $100 \%$ & $18 \%$ & $19 \%$ & $0 \%$ & $64 \%$ & $100 \%$ \\
\hline Iganga TC & $6 \%$ & $16 \%$ & $0 \%$ & $78 \%$ & $100 \%$ & $19 \%$ & $11 \%$ & $1 \%$ & $69 \%$ & $100 \%$ \\
\hline Kalangala TC & $0 \%$ & $0 \%$ & $0 \%$ & $0 \%$ & $0 \%$ & $30 \%$ & $40 \%$ & $0 \%$ & $30 \%$ & $100 \%$ \\
\hline Kiboga TC & $42 \%$ & $35 \%$ & $0 \%$ & $24 \%$ & $100 \%$ & $61 \%$ & $0 \%$ & $0 \%$ & $39 \%$ & $100 \%$ \\
\hline Kitgum TC & $13 \%$ & $0 \%$ & $0 \%$ & $87 \%$ & $100 \%$ & $16 \%$ & $16 \%$ & $0 \%$ & $68 \%$ & $100 \%$ \\
\hline Kotido TC & $37 \%$ & $0 \%$ & $0 \%$ & $63 \%$ & $100 \%$ & $18 \%$ & $37 \%$ & $3 \%$ & $42 \%$ & $100 \%$ \\
\hline Luwero & $35 \%$ & $19 \%$ & $0 \%$ & $46 \%$ & $100 \%$ & $26 \%$ & $19 \%$ & $1 \%$ & $54 \%$ & $100 \%$ \\
\hline Moroto MC & $6 \%$ & $42 \%$ & $0 \%$ & $52 \%$ & $100 \%$ & $3 \%$ & $5 \%$ & $83 \%$ & $9 \%$ & $100 \%$ \\
\hline Moyo TC & $9 \%$ & $35 \%$ & $0 \%$ & $57 \%$ & $100 \%$ & $17 \%$ & $29 \%$ & $0 \%$ & $54 \%$ & $100 \%$ \\
\hline Mpigi TC & $48 \%$ & $0 \%$ & $0 \%$ & $52 \%$ & $100 \%$ & $26 \%$ & $32 \%$ & $0 \%$ & $42 \%$ & $100 \%$ \\
\hline Mubende TC & $34 \%$ & $0 \%$ & $0 \%$ & $66 \%$ & $100 \%$ & $25 \%$ & $23 \%$ & $0 \%$ & $53 \%$ & $100 \%$ \\
\hline Njeru TC & $30 \%$ & $11 \%$ & $0 \%$ & $59 \%$ & $100 \%$ & $21 \%$ & $20 \%$ & $0 \%$ & $60 \%$ & $100 \%$ \\
\hline Soroti & $12 \%$ & $0 \%$ & $0 \%$ & $88 \%$ & $100 \%$ & $14 \%$ & $16 \%$ & $13 \%$ & $58 \%$ & $100 \%$ \\
\hline Tororo MC & $14 \%$ & $23 \%$ & $0 \%$ & $63 \%$ & $100 \%$ & $15 \%$ & $10 \%$ & $1 \%$ & $75 \%$ & $100 \%$ \\
\hline Wobulenzi & $0 \%$ & $0 \%$ & $0 \%$ & $0 \%$ & $0 \%$ & $31 \%$ & $20 \%$ & $0 \%$ & $48 \%$ & $100 \%$ \\
\hline Average & $28 \%$ & $15 \%$ & $0 \%$ & $59 \%$ & & $23 \%$ & $22 \%$ & $17 \%$ & $50 \%$ & \\
\hline \multicolumn{11}{|c|}{ TC- - Town Council } \\
\hline \multicolumn{11}{|c|}{ TC - Municipal Council } \\
\hline Other comprise & Licen & ce Fees etc & & & & & & & & \\
\hline
\end{tabular}

Source: Analysis of Districts and Urban Councils Budgets for 1996/97_1997/98 by Ministry of Local Government.

After graduated tax was abolished, the government announced three main initiatives to fill the revenue gap: a graduated tax compensation scheme, two new local government taxes (local service tax and local hotel tax), and a 1 per cent increase in the rate of VAT.

The graduated tax compensation scheme was introduced shortly after suspension of graduated tax to compensate local government for the revenue that it had lost (Local Government Finance Commission 2012). However, by 2011/2012 the scheme was paying out less than a third of what had been budgeted. In municipalities such as Mbarara, the scheme ran for a period of five years, after which it was abruptly stopped (interview with officials in Mbarara Municipality). In Kabale, where the district used to collect approximately UGX3 billion annually in graduated tax, the compensation scheme provided only UGX1.6 billion, which was also abruptly stopped (interview with local government official in Kabale district). In the end, local government was left with inadequate compensation.

To replace graduated tax, in 2008 the government introduced a local service tax and local hotel tax. Local service tax is imposed on all persons earning an income from employment or self-employment. Local hotel tax is imposed on occupants of hotel rooms. At the time of their introduction, it was estimated that the two taxes would contribute approximately UGX67 billion to local government revenue (CSBAG 2017). However, by 2011/2012 the two taxes combined were raising only about UGX6 billion annually (Local Government Finance 
Commission 2012). In practice, local service tax has been imposed mostly on those in formal employment (interviews with officials in Mbarara District Local Council and Kabale Municipality). Essentially, the bulk of these individuals are government employees and employees of big companies where tax is withheld from employment income and remitted to local government. Most other individuals remain untaxed. Local government officials in Mbarara, Kabale, Tororo and Kapchorwa informed the researchers that it is difficult to collect local service tax and local hotel tax even from some businesses in the formal sector, because many of them resort to keeping two separate books of account. In Tororo, for example, one large company was found to be keeping two payroll records: one for the purpose of remitting Pay As You Earn (PAYE) to the Uganda Revenue Authority (URA), and another less populated one for the purposes of local service tax. Similarly, some hotel owners keep separate books of account: one to share with security organisations (which often contain a more comprehensive list), and another to share with local government (having fewer names of hotel occupants). The other challenge with the local hotel tax is that it mainly benefits urban local councils. Most rural areas lack hotel infrastructure (interview with local government officials in Mbarara, Kabale, Gulu, Moroto, Tororo and Kapchorwa).

The other initiative that the government announced when it abolished graduated tax was that it would increase the rate of VAT from 17 per cent to 18 per cent, with the 1 per cent increase being earmarked for local government transfers (Local Government Finance Commission 2012). The Ministry of Finance, Planning and Economic Development projected that this increase would result in an additional UGX153 billion in VAT. The researchers were not able to establish whether this increase was realised. What is certain, however, is the fact that the 1 per cent was never earmarked for local government transfers. In an interview with officials in the Ministry of Finance, the officials explained that the Ministry understood that the abolition of the tax was going to place an additional burden on central government to support local government. However, they confirmed that the 1 per cent was never specifically earmarked for this.

As at 2012, locally generated revenue constituted less than 5 per cent of total financing of local government budgets (Local Government Finance Commission 2012). This contribution is much lower when specific district budgets are analysed. In Kabale, for example, locally generated revenue constitutes only 1 per cent of the district budget (interviews with officials in Kabale District). In Mbarara, Kisoro and Gulu, the contributions are 2 per cent, less than 2 per cent and less than 1 per cent respectively (interviews with local government officials in the respective districts). Table 3 below represents a summary of all local government revenue after the abolition of graduated tax.

Table 3 Local government revenue after abolition of graduated tax (UGX billion)

\begin{tabular}{|c|c|c|c|c|c|c|c|c|c|c|c|c|c|}
\hline \multirow[b]{2}{*}{$F / Y$} & \multicolumn{6}{|c|}{ Local government Revenue } & \multicolumn{5}{|c|}{ Revenue Share (\% of Total LG Financing) } & \multicolumn{2}{|c|}{ LST \& LHT (Combined) - \% } \\
\hline & LST & LHT & Other Taxes & Grants & Other Rev & Total Rev & LST & LHT & Other Taxes & Grants & Other Rev & Own Rev & Total LG Rev \\
\hline $2008 / 09$ & 3.8 & 1.0 & 24.9 & $1,211.2$ & 89.0 & $1,329.9$ & $0.3 \%$ & $0.1 \%$ & $1.9 \%$ & $91.1 \%$ & $6.7 \%$ & $4.1 \%$ & $0.4 \%$ \\
\hline $2009 / 10$ & 9.2 & 1.5 & 45.6 & $1,410.3$ & 86.5 & 1,553.1 & $0.6 \%$ & $0.1 \%$ & $2.9 \%$ & $90.8 \%$ & $5.6 \%$ & $7.5 \%$ & $0.7 \%$ \\
\hline $2010 / 11$ & 6.5 & 0.9 & 31.6 & $1,586.7$ & 72.0 & $1,697.7$ & $0.4 \%$ & $0.1 \%$ & $1.9 \%$ & $93.5 \%$ & $4.2 \%$ & $6.7 \%$ & $0.4 \%$ \\
\hline $2011 / 12$ & 7.1 & 1.2 & 29.3 & $1,783.8$ & 80.0 & $1,901.3$ & $0.4 \%$ & $0.1 \%$ & $1.5 \%$ & $93.8 \%$ & $4.2 \%$ & $7.0 \%$ & $0.4 \%$ \\
\hline $2012 / 13$ & 10.8 & 1.1 & 33.6 & $1,925.8$ & 93.9 & $2,065.2$ & $0.5 \%$ & $0.1 \%$ & $1.6 \%$ & $93.3 \%$ & $4.5 \%$ & $8.5 \%$ & $0.6 \%$ \\
\hline $2013 / 14$ & 10.1 & 1.3 & 38.7 & $2,168.4$ & 102.9 & $2,321.4$ & $0.4 \%$ & $0.1 \%$ & $1.7 \%$ & $93.4 \%$ & $4.4 \%$ & $7.4 \%$ & $0.5 \%$ \\
\hline $2014 / 15$ & 11.7 & 2.9 & 45.1 & $2,448.0$ & 117.6 & $2,625.2$ & $0.4 \%$ & $0.1 \%$ & $1.7 \%$ & $93.2 \%$ & $4.5 \%$ & $8.2 \%$ & $0.6 \%$ \\
\hline Average & 7.4 & 1.2 & & & & & $0.4 \%$ & $0.1 \%$ & $2.1 \%$ & $92.8 \%$ & $4.7 \%$ & $7.1 \%$ & $0.5 \%$ \\
\hline
\end{tabular}

Source: Local Government Finance Commission. ${ }^{11}$

112016 data from draft report on file with LGFC. 
This situation has been exacerbated by the recent creation of new districts. In 1992, when decentralisation was introduced in Uganda, there were thirty-nine districts (Steiner 2007). By $2006 / 2007$ the number of districts had increased to seventy-nine (Green 2008). At the time of writing this paper, there were 112 districts (Uganda Bureau of Statistics 2014). Generally, local government in Uganda can be loosely categorised as local government in rural areas and local government in urban areas. In rural areas, the local authority structure consists of districts and sub-county councils. In urban areas, the local authority comprises either the city, municipality or town councils, depending on the size (Livingstone and Charlton 2001). The creation of districts is in most cases politically motivated with no rationale criteria. For instance, counties have been converted into districts. The creation of a new district resulted in the creation of at least two new urban local councils (Local Government Finance Commission 2012).

Most taxable economic activities are found in urban councils, where local government can collect taxes on property, trading licences and market fees from well-established markets. District councils, in particular, are at a disadvantage because they have limited sources of revenue when compared to urban and town councils (interview with former official of Kabale Municipality). In Mbarara district, for example, as a result of the creation of new district administrative centres, taxes such as the local service tax and local hotel tax are now administered by town councils and municipalities, leaving districts with very few taxable activities (interview with officials in Mbarara District). Similarly, rural parts of Mbarara, such as Kashari north, Kashari south and Rwampara, have no hotels. While town councils like Kabale are able to collect local hotel tax, given the fact that they are financially and administratively autonomous from the district, this tax is not remitted to the district. Similar challenges were cited in Gulu, Kisoro and Tororo districts. As seen below, the share of taxes to rural local government has decreased, while that to urban local government has increased.

Table 4 Rural urban revenue trends (UGX million)

\begin{tabular}{|l|l|l|l|}
\hline Level of administration & $\mathbf{2 0 0 8 / 2 0 0 9}$ & $\mathbf{2 0 0 9 / 2 0 1 0}$ & $\mathbf{2 0 1 0 / 2 0 1 1}$ \\
\hline Town councils & $9,954,395$ & $21,350,255$ & $27,755,332$ \\
\hline Municipalities & $10,031,655$ & $25,110,523$ & $32,643,680$ \\
\hline Districts & $72,892,984$ & $54,201,609$ & $56,911,689$ \\
\hline Total & $92,879,034$ & $100,662,387$ & $117,310,701$ \\
\hline Share of rural LGs (\%) & $78 \%$ & $54 \%$ & $49 \%$ \\
\hline Share of urban councils & $22 \%$ & $46 \%$ & $51 \%$ \\
\hline
\end{tabular}

Source: Local Government Finance Commission 2012.

For most rural local government, this means increased reliance on central government to fund their budgets. As at 2012, transfers from central government to local government had on average increased to more than 85 per cent of local government funding (Local Government Commission 2012). The bulk of this funding is conditional, meaning that local government has little or no discretion over how to spend the money (Ndawula 2009).

While it has often been argued that graduated tax (particularly after the 1990s) rarely funded public services, this was not the case for all local governments. In some instances, part of the revenue realised from graduated tax was used to fund important public programmes, especially in the health and education sectors (Local Government Finance Commission 2012). Some local government officials maintain that the revenue raised was invested in projects that benefited their communities (interviews with officials in the Local Government Finance Commission). In Mbarara district, for example, 25 per cent of the tax collected was 
often returned to the villages to support building of schools, provide water, construct roads and fund local council courts (interview with official in Mbarara District Local Council). In Kabale, 65 per cent of graduated tax revenue was retained in the district to enable subcounties to construct local government staff houses, top up allowances of health workers, and facilitate the construction and operation of local courts and sports activities (interviews with officials from Kabale District Local Government). Ultimately, the argument that graduated tax was used only to fund operational costs and/or was embezzled by public officials is not sustainable in every local government, and it is important that a distinction is drawn between local government that used it to benefit their communities, and those that did not. In areas where revenue from graduated tax was used to the benefit of the population, its reinstatement is supported by both the technocrats in local government and sections of the community (interviews with local government officials and focus group discussions in Kabale, Mbarara and Tororo).

What explains the desire of Uganda's subnational governments to have the tax reinstated when compared to their counterparts in Kenya and Tanzania? After all, graduated tax was the major source of own revenue in all three countries. We argue that the explanation lies at least in part - in the countries' histories of decentralisation more generally. In Kenya decentralisation has often been a contentious issue, with some ruling parties (such as the Kenya African National Union) being more in favour of a strong central government (World Bank 1992). In 1996, the government of Kenya established a Local Government Commission to look into ways in which subnational government systems could be strengthened. The commission recommended various reforms. The government endorsed many of the reforms and committed to supporting the revitalisation of local authorities through the provision of reliable sources of revenue and central government grants. However, in 1969 parliament passed the Transfer of Function Act, which had the effect of transferring the responsibility for major services such as primary education and health from local authorities to central government (with the exception of seven of the largest municipalities). Following this the administration of graduated tax was transferred to the central government, until it was finally abolished. This would explain, at least in part, why there was not much opposition in parliament to its abolition. For a long time it had been administered by the Ministry of Finance, and its abolition ceased to be a problem for subnational government as long as the latter continued to fund major local government services.

Similarly, Fjeldstad and Therkildsen (2008) argue that while the abolition of the poll tax in Tanzania in 1969 was largely premised on the fact that the tax was coercive in nature, there was also a political explanation. Specifically, the ruling party at the time was concerned about local political elites and cooperatives using subnational government to enhance their personal interests. Shortly after the poll tax was abolished, in 1972, rural local authorities were disbanded. Urban councils were abolished one year later. The local government system was reintroduced in 1982, and the development levy was reintroduced in 1984 . This new tax was contentiously opposed in parliament and passed with a margin of only two votes. By the time it was abolished in 2003, its contribution to total local revenue had significantly reduced. Here again, one can conclude that the apparent absence of a call for the reintroduction of the tax from subnational government officials may have something to do with the historically fragile nature of the country's local government institutional structures.

\subsection{Graduated tax as a symbol of pride and productivity}

Many of the individuals who want the reintroduction of graduated tax are in rural areas. For most of them, this nostalgia revolves around issues of gender and productivity. It is both 
about the perception that men have of themselves and how women perceive them. Many of the men who are nostalgic about the tax are the older generation. Their attitude cannot be explained on grounds of rationale self-interest. A more plausible explanation is the social standing that was associated with being able to honour one's taxpaying obligations. They recall the sense of pride and patriotism that was associated with possessing a tax receipt (interviews with officials in the Local Government Finance Commission and with community members in Kabale, Mbarara, Gulu, Moroto, Tororo and Kapchorwa Districts). In Gulu, for example, when men got together for social gatherings, they often compared their tax receipts to establish who had paid more taxes. Proof of payment was a symbol of good standing in the community. Similarly, the number of graduated tax tickets one had was associated with their age, maturity and sense of responsibility, all of which are important attributes among African communities. More specifically, those with the most paid tickets were considered elders, and commanded a lot of respect from their peers (focus group discussions in Kabale, Kisoro, Mbarara, and interviews with local government officials in Tororo).

Among the pastoral communities in Mbarara, where respect and wealth was derived from the number of cows kept in your kraal, prosperous farmers demanded to pay the highest possible assessment - UGX100,000. To them, paying less was to place themselves in the less privileged and unenviable class of 'mediocre' farmers. Thus, in these pastoral communities, the more taxes they paid, the more respect they were accorded (interview with official from Mbarara District local government). For this segment of the population, the abolition of the tax took away one of the instruments that was used to show standing in society.

Women who would like the reintroduction of the tax do so on the grounds that it compelled their men to be productive (interview with SEATINI officials). Men had to go to work because they had an obligation to pay taxes. The increased productivity meant that they could provide for their families and, in certain cases, even save some money (interview with officials in the Local Government Finance Commission). Engaging in productive activities also meant that there was less crime. Some argued that the tax created harmony between husbands and wives, because they worked closely together to achieve the objective of paying taxes (interview with official in Mbarara District Local Council). Sometimes women would pay the tax on behalf of their men, and keep the tax receipts until the men refunded their money (interview with official in Kyanamira sub-county, Kabale District). ${ }^{12}$ When the proposal to abolish graduated tax was made in parliament in 2004, the member of parliament for Arua (a woman) said:

I would like to inform my colleagues that in Arua the Graduated Tax you are saying is gender insensitive has been shifted to the women to pay for their husbands ... The women of Arua have been paying Graduated Tax for their husbands. During the time of collection, because of harassment, the men normally go to sleep in the ceilings, so it is their wives to pay the Graduated Tax so that their husbands are not arrested.

(Parliament of the Government of Uganda 2004).

Women in districts such as Lamwo have called for the reintroduction of the tax because they complain that since it was abolished many of their men are no longer interested in working (interview with SEATINI officials). Similarly, in a focus group discussion that we held in Bugongi, Kabale district, the women stated that they wanted graduated tax reintroduced because ever since it was abolished the men in the community had become lazy and were

12 See also Mucunguzi, J., 'Bakiga women pay tax for husbands', The Monitor 25 July 1997. 
no longer providing for their households. It was also reported that the lack of pressure to pay taxes has resulted in many young men spending most of their time consuming alcohol (interview with official in Kabale District). This has in turn increased the cases of domestic violence.

The impact of the abolition of the tax on men's productivity has been exacerbated by the fact that the government subsidises a number of services, such as the provision of universal primary education and universal secondary education (interview with officials in the Local Government Finance Commission). By taking away the bulk of the financial burden for funding an education, there is less pressure on men to work. At the same time, irrespective of the provision of subsidised primary and secondary school education, some argue that the abolition of graduated tax increased the rate of school drop-outs and idleness, particularly among male youths (interview with subcounty officials in Bukinda, Kabale District). Students were exempt from paying graduated tax. This had the positive impact of keeping them in school to avoid having a tax liability. Its abolition means that those who were not keen on studying dropped out of school.

It is important to understand this gendered argument in the context of the rural setting, where most families are able to access food from their land because they engage in peasant farming. Most work on the land is done by women and children. Graduated tax compelled men to go out and earn an income to avoid being arrested. Whether or not a tax should be used to serve this purpose is a question beyond the scope of this paper. What cannot be ignored is the fact that it did in many ways serve that purpose, and that women felt that they benefited from it. In particular, having men work in this manner eased their burden of being both household caretaker and the provider. It also reduced the time available for men to engage in gambling and consumption of alcohol, both of which were often detrimental to women's welfare.

While one may argue that the women's sentiments are part of a larger problem of the tensions existing between men and women, even in the absence of a tax, there is at least some history to suggest that this particular tax was introduced to compel people to work in the cash economy. As noted in the preceding discussion, poll taxes were introduced in Uganda in 1905 to compel Africans to work so that they could support the protectorate government through the payment of taxes (Davey 1974). Some have argued, for example, that because it was difficult for colonialists to coerce Africans into doing things that were beneficial to colonies (such as construction of the railway in East Africa), they introduced taxation so the Africans were either forced to seek employment from colonial masters or farm their lands so that they could pay the taxes (Parliament of the Republic of Uganda 2004). ${ }^{13}$ In 2004, when the abolition of graduated tax was being discussed in Uganda's parliament, one member stated:

The threat of taking the household husband to prison if he did not pay tax was so effective that by 3 o'clock the wife was the one who used to wake the husband. 'Let us go and grow cotton so that you are able to gain our freedom, otherwise if you go away where are we going to live?'

\footnotetext{
13 While the view that taxes served the purpose of compelling Africans to work may be partly correct, political scientists argue that in every natural state there is reluctance to work. In such societies, therefore, taxes serve the purpose of compelling people to work in order to meet their obligation to the state. It is therefore most likely that the tax would have had the same effect in developed countries as we know them today during the time that they were in their primitive stage. For literature on natural state generally see North (2009).
} 


\section{Conclusion}

The story of the abolition of graduated tax is rather more complex than is sometimes suggested. Our research reveals that, while the tax was unpopular for various reasons, there are segments of the population for which it had positive attributes. For some women, the tax created incentives for men to work, thereby having a positive impact on gender relations more broadly. For some men, particularly the older generation, it was about the social standing in the community that was associated with being able to honour one's tax obligations. Similarly, it encouraged students, who were exempt from the tax, to stay in school.

It is notable from our findings that women have been vocal in advocating for the revival of the tax primarily to induce their spouses to participate in gainful employment, thereby avoiding idleness and unsocial habits such as alcoholism and gambling. Additionally, this would ease the women's responsibilities both as household caretaker and provider.

It should also be remembered that opposition to the abolition of graduated tax among rural communities is not new. In an inquiry into Uganda's local government system in the late 1980 s, the commissioners to the inquiry noted that several citizens (mainly peasants) were overwhelmingly opposed to the abolition of graduated tax (Republic of Uganda 1987). Their objections were based on two main grounds. First, they felt that if the tax was abolished and replaced with an indirect tax, they would not be able to ascertain how much tax was being collected from them. Second, that the indirect tax could turn out to be more regressive.

However, given the political sensitiveness of the tax, it is highly unlikely that the government will reintroduce it. This means that the way forward is for local government to maximise the potential of existing taxes. For taxes such as the local service tax and local hotel tax, our research reveals that part of the problem lies in implementation, which emanates from insufficient information. One of the ways in which this problem can be resolved is for local government to work closely with central government agencies such as the URA to share taxpayer information. Collaboration between the URA and local government has already started in districts such as Kampala, where the Kampala Capital City Authority and URA are working jointly on the Taxpayer Registration Expansion Project to register as many taxpayers as possible. Other local governments should consider introducing similar initiatives.

Another prospect for increasing locally generated revenue, particularly for urban local councils, is to put more effort into collecting property taxes. In Tanzania, for example, when the development levy was abolished local government intensified collection from taxes that existed in law but had not been previously enforced to make up for the revenue lost (World Bank 2006). Among these were property taxes, plying fees and parking fees. Existing research shows that property taxes have great revenue potential for local government in developing countries, but this potential is rarely tapped into (Goodfellow 2015; Jibao and Prichard 2013).

Yet, more critically, it is important to ask the question: has fiscal decentralisation in Uganda failed so far because of the inherent absence of a tax base at the subnational level, or is it due to an underlying lack of commitment to decentralisation generally? More specifically, why does subnational government in Uganda continue to struggle to raise own revenue despite the vast amount of resources that both donors and governments have sunk into projects targeting fiscal independence? Could the explanation be, as has been argued by 
various scholars elsewhere, that national governments - or at least the politicians who run them - do not want fiscally independent subnational governments? Smoke and Lewis (1996) begin their analysis of this dilemma by observing that:

The recent history of public sector decentralisation in developing countries is primarily a story of disappointing performance or outright failure. With few exceptions, the literature is full of stories about extensive and costly fiscal decentralisation programmes that have made only limited progress in meeting their stated goals.

They conclude that one explanation for the failure of fiscal decentralisation is the fear of central government ministries that they will lose their powers to subnational government. Elsewhere, Khemani (2015) argues that 'partial decentralisation', characterised by huge reliance of subnational government on grants from national government, can be explained by the need of central government-level politicians to keep subnational government fiscally dependent on them so that they can use the relationship to get votes or otherwise exercise political control. ${ }^{14}$ In other words, by creating subnational government that has 'low capacity, almost no access to own tax bases, and spending and decision-making powers restricted to the administering of higher-tier grants for local infrastructure', those in power are able to target grants to particular interest groups in exchange for political support (Khemani 2015). This argument also finds support in Green (2010), who argues that, in countries such as Uganda, the creation of new subnational units (and particularly the explosion of districts) can be attributed to the use of decentralisation as a tool of patronage.

We observed in Section 3 that when decentralisation was introduced in Uganda in 1992, there were thirty-nine districts. This has since increased to 112 districts. This fragmentation has drastically eroded the tax base of some subnational governments, and invariably increased their reliance on grants from central government. Even if the performance of property taxes is to be improved, this will benefit only a few urban local governments. The majority will continue to rely on central government. Without critically addressing the relationship between politics at the national level and the creation of new subnational governments, fiscal decentralisation is likely to remain a mere aspiration.

The authors note, for example, that in a number of African, Latin American, South and East Asian countries, more than $90 \%$ of subnational government expenditure is financed by grants from national governments. Similarly, partial decentralisation is characterised by an increasing fragmentation of local government units. 


\section{References}

Bahiigwa, G., Ellis, F., Fjeldstad, O-H. and Vegard Iversen (2004) Uganda Rural Taxation Study: Final Report, EPRC/ODG/CMI

Bakibinga D. (2012) Revenue Law in Uganda, Nairobi: Law Africa Publishing

CSBAG (2017) Assessing the Viability of Local Service Tax and Other Local Revenue Sources: A Case of Kibaale, Mubende, Apac, Gulu and Agago Districts, Issue Brief, Civil Society Budget Advocacy Group

Davey, K. (1974) Taxing a Peasant Society, London: Charles Knights and Co.

Development Consultants International Limited (2005) A Study on the Implications of the Proposed Suspension of Graduated Tax on Local Government Financing and Decentralization Process In Uganda, DCI, Kampala

Fjeldstad, O-H. (2016) Revenue mobilization at subnational levels in Sudan, Sudan Report no SR2016:1, Bergen: Chr. Michelsen Institute

and Semboja, J. (2000) 'Dilemmas of fiscal Decentralisation', Forum for Development Studies 27(1): 7-14

and Therkildsen, O. (2008) 'Mass Taxation and State-Society Relations in East Africa', in D. Brautigam, O-H. Fjeldstad and M. Moore (eds), Taxation and State Building in Developing Countries, Cambridge: Cambridge University Press

Gardner, L. (2012) Taxing Colonial Africa: the Political Economy of British Imperialism, Oxford: Oxford University Press

Ghai, D. (1966) Taxation for Development : A Case Study of Uganda, Nairobi: East African Publishing House

Goodfellow, T. (2015) Taxing the Urban Boom: Property Taxation and Land Leasing in Kigali and Addis Ababa, ICTD Working Paper 38, Brighton: International Centre for Tax and Development/IDS

Green, E. (2010) 'Patronage, District Creation, and Reform in Uganda', Studies in Comparative International Development 45(1): 83-103

- (2008) District Creation and Decentralisation in Uganda, Working Paper No. 24, Crisis State Working Paper Series No. 2, LSE Development Studies Institute

IMF (2012) Sudan: Selected Issues Paper, Washington DC: International Monetary Fund

Jibao, S. (2009) Property Taxation in Anglophone West Africa: Regional Overview, Working Paper WP09AWA1, Lincoln Institute of Land Policy 
Prichard, W. and van den Boogaard, V. (2017) Informal Taxation in Post Conflict Sierra Leone: Taxpayers' Experiences and Perceptions, ICTD Working Paper 66, Brighton: International Centre for Tax and Development/IDS

(2013) Rebuilding Local Government Finance After Conflict: The Political Economy of Property Tax Reform in Post Conflict Sierra Leone, ICTD Working Paper 12, Brighton: International Centre for Development Studies/IDS

Kenya National Assembly (1973) Kenya National Assembly Official Record (Hansard) March 27-May 18, 1973

Khemani, S. (2015) 'Political Capture of Decentralization: Vote Buying Through Grants to Local Jurisdictions', in J-P. Faguet and C. Poschl (eds), Is Decentralization Good for Development. Perspectives from Academics and Policymakers, New York: Oxford University Press

Kizza-Besigye (2001) The Next Five Years 2001-2006 (campaign manifesto)

Kjaer, A. (2009) 'Sources of Local Government Extractive Capacity: The Role of Trust and Pre-colonial Legacy in the Case of Uganda', Public Administration and Development 29(3): 228-38

and Katera, L. (2017) 'Revenue Bargaining Dynamics in Local Governments: From Fiscal Contract to Dictates (draft Working Paper, unpublished)

and Therkildsen, O. (2013) 'Elections and Landmark Policies in Tanzania and Uganda', Democratization 20(4): 592-614

Kwatemba, J. (2017) Kenya III: Context and History, 1-19, <wwwtaxjustice-and-poverty.org>, accessed 19 and 27 November 2017

Livingstone, I. and Charlton, R. (2001) 'Financing Decentralised Development in a LowIncome Country: Raising Revenue for Local Government in Uganda', Development and Change 32(1): 77-100

(1998) 'Raising Local Authority District Revenues through Direct Taxation in a Low-income Developing Country: Evaluating Uganda's GPT', Public Administration and Development 18(5): 499-517

Local Government Finance Commission (2012) Review of Local Government Financing: Financing Management and Accountability for Decentralized Service Delivery, $<$ https://www.lgfc.go.ug/?q=download/file/fid/108>

Mamdani (2008) 'A Response to Critics', Development and Change 2(2): 351-366

Mugume, A. (2004) 'Local Government Graduated Tax and Compliance Implications: The case of Kampala and Mubende Districts', Eastern Africa Journal of Rural Development 20(1): 126 
Mukasa, A. (2002) Options in Administration of Graduated Tax in Uganda, report prepared for Hon. Okullo Epak, Parliament of Uganda

Ndawula, J. (2009) The Effect of Suspending Graduated Tax in Lower Local Districts: A case of Mukono District (Makerere University MA (PAM) Dissertation)

North, D., Wallis, J. and Weingast, B. (2009) Violence and Social Orders, Cambridge University Press

Parliament of the Republic of Uganda (2004) Parliamentary Debates: Hansards, 15 April, Kampala

— (2002) Parliamentary Debates: Hansards 13 August, Kampala

Republic of Uganda (1987) Report of the Commission of Inquiry into the Local Government System, Kampala

Smoke, P. and Lewis, B. (1996) 'Fiscal Decentralization in Indonesia: A New Approach to an Old Idea', World Development 24(8): 1281-1299

Steiner, S. (2007) 'Decentralisation and Poverty: Conceptual Framework and Application to Uganda', Public Administration and Development 27: 175-185

Tarus, I. and Nyambura Njoroge, R. (2015) 'The Political Economy of Post-Colonial Taxation in Kenya, 1973-1995', Historical Research Letter 18: 59-66

Therkildsen, O. (2006) The Rise and Fall of Mass Taxation in Uganda: 1900-2005, DIIS Working Paper 25

Uganda Bureau of Statistics (2014) National Population and Housing Census 2014: Provisional Results <http://www.ubos.org/onlinefiles/uploads/ubos/NPHC/NPHC\%202014\%20PROVISION AL\%20RESULTS\%20REPORT.pdf>

Vallibhoy, F. (1965) Tax Inquiry Report 1964/1965, Entebbe: Government Printer

Vision Reporter (2004) 'Graduated Tax to be Suspended for Ten Years', $<$ https://www.newvision.co.ug/new_vision/news/1101142/graduated-tax-suspended>

Waris, A. (2007) 'Taxation without Principles: A Historical Analysis of the Kenya Tax System', Kenya Law Review 276(1): 272

World Bank (2006) Local Government Taxation Reform in Tanzania: a Poverty and Social Impact Analysis Report No.34900-TZ $<$ http://siteresources.worldbank.org/EXTSOCIALDEVELOPMENT/Resources/2443621164107274725/3182370-1164201144397/TZ-PSIA-Summary.pdf>

_ (1992) Kenya Local Government Finance Study, Report No. 8997-KE, Washington DC: World Bank 